\title{
THE IODINE ABSORPTION AS A FACTOR IN THE EXAMINATION OF OTTO OF ROSE.
}

\author{
Frederick Hudson-Cox and William H. Simmons.
}

(Read at the Meeting, March 2, 1904.)

The iodine absorption of essential oils appears to have received very little attention from chemists. Barenthin first drew attention to it in 1886; Kremel did a little more in 1888, and Williams, Snow, and Davies in 1889, the last-named examining, perhaps, the largest number of samples. More recently (the early part of last year) Sangté-Ferrière and Cuniasse (Journ. de Pharm., 1903, 169) added a further number to the list, but none of these examined sufficient samples of any particular oil to be of real value, and those who have special facilities for observation do not appear to have carried out any experiments with the process.

We quite agree that the iodine absorption is not applicable to all essential oils. Still, it seems to us that in some cases it does give extremely valuable information, and in no case, perhaps, is it more useful than in the examination of otto of rose.

It has always been considered difficult to detect careful adulteration of this oil by chemical means, and the artificial otto recently put upon the market by various firms has added to the difficulty. It was the fact that large quantities of this substance were stated to be imported into the otto districts which first.raised our curiosity. As chemists to a firm using very considerable quantities of otto of rose, it was of interest to us to know what became of this imported article, for, although excellent in its way, it did not seem likely that the growers of the natural should prefer the artificial product, and we could not learn that any of it came out of the country under its own name.

Two makes of artificial otto gave in our hands the following data, ${ }^{*}$ from which

\begin{tabular}{|c|c|c|c|c|}
\hline & \multicolumn{2}{|c|}{ No. I. } & \multicolumn{2}{|c|}{ No. II. } \\
\hline Specific gravity $\frac{30^{\circ}}{15 \cdot 5^{\circ}} \mathrm{C} . \ldots$ & $\begin{array}{c}\text { A. } \\
0 \cdot 8629\end{array}$ & $\begin{array}{c}\text { B. } \\
0.8717\end{array}$ & $\begin{array}{c}A . \\
0.8589\end{array}$ & $\begin{array}{c}\text { B. } \\
0.8658\end{array}$ \\
\hline $\begin{array}{cc}\text { Optical rotation } 30^{\circ} & \mathrm{C} . \\
100 \text { millimetre tube } & \ldots \\
\text { Saponification number } & \ldots \\
\text { Setting point } \quad \ldots & \ldots\end{array}$ & $\begin{array}{c}-0^{\circ} 50^{\prime} \\
20.5 \\
22 \cdot 5^{\circ} \mathrm{C} .\end{array}$ & $\begin{array}{c}-1^{\circ} 20^{\prime} \\
13 \cdot 4 \\
-\end{array}$ & $\begin{array}{c}-0^{\circ} 14^{\prime} \\
3 \cdot 8 \cdot 8 \\
21 \cdot 9^{\circ} \mathrm{C} .\end{array}$ & $\begin{array}{l}-0^{\circ} 52^{\prime} \\
5 \cdot 7\end{array}$ \\
\hline
\end{tabular}

it will be seen that large quantities could be added to the natural oil without fear of detection by the ordinary methods; indeed, a mixture of 1 part artificial and 2 parts natural oil of good quality gave figures well within the accepted limits, and in odour was not by any means to be despised. We have not determined the acetyl number, because, owing to the large quantity required and the range for the natural oil, we do not consider it generally applicable. The refractive index gives usefu

- These ottos can be obtained either with or without stearoptene. In the above table A is with, and $\mathrm{B}$ without, in each case. 
information in some cases, but since Parry has promised a further report on that, we have not examined the test at any length.

While debating as to what course we should pursue, Sangté-Ferrière and Cuniasse's paper revived our interest in the iodine absorption, and we determined to see if some use could not be made of that method, and this we did, with results which we think worthy of bringing before the Society.

In our experiments we have used from 0.1 to 0.2 grammes of otto, added 10 c.e. of 90 per cent. alcohol, 25 c.c. Hübl solution, and allowed to stand for three hours at the temperature of the laboratory. It has been stated that the temperature has a marked effect upon the absorption, but although we have worked at all temperatures from $4^{\circ}$ to $27^{\circ} \mathrm{C}$., we have not found any appreciable difference. The age of the Hübl, however, is of very great importance, a solution three weeks old being much less active than a freshly-prepared one. The plan which we find to give the best results is to keep the iodine and mercuric chloride solutions separate, and to mix them the evening before they are required.

Another point is that the titration must be carried out as quickly as possible, as the colour rapidly comes back. These remarks, of course, apply also to the fixed oils more or less, although not to anything like the extent they do here.

We also in some cases substituted 10 c.c. chloroform for the alcohol in order to dissolve the stearoptene, for fear the latter should enclose some of the oil, and so prevent or retard its absorption of iodine, but we found it made no difference to the result.

For use in our experiments we first took samples of otto of known brands which had previously been examined by the ordinary methods and passed as being of good quality. We examined, in all, twenty of these samples, taken from the seasons 1896 to 1903 inclusive, and found them to have an absorption of from 187 to 194 . We give a table of a few of these :

\begin{tabular}{c|c|c|c|c|c}
\hline No. & $\begin{array}{c}\text { Specific gravity } \\
\frac{30^{\circ}}{15 \cdot 5^{\circ}} \mathrm{C.}\end{array}$ & $\begin{array}{c}\text { Rotation } 30^{\circ} \mathrm{C} . \\
100 \cdot \text { millimetre } \\
\text { Tube. }\end{array}$ & $\begin{array}{c}\text { Saponification } \\
\text { Number. }\end{array}$ & $\begin{array}{c}\text { Setting- } \\
\text { Point. }\end{array}$ & $\begin{array}{c}\text { Iodine } \\
\text { Number. }\end{array}$ \\
\hline 1 & $0 \cdot 8531$ & $-2^{\circ} 40^{\prime}$ & $7 \cdot 5$ & $20 \cdot 4^{\circ} \mathrm{C}$. & 187 \\
2 & $0 \cdot 8512$ & $-2^{\circ} 35^{\prime}$ & $8 \cdot 3$ & $21 \cdot 0^{\circ} \mathrm{C}$. & 191 \\
3 & $0 \cdot 8541$ & $-2^{\circ} 7^{\prime}$ & $8 \cdot 1$ & $20 \cdot 8^{\circ} \mathrm{C}$. & 192 \\
4 & $0 \cdot 8587$ & $-2^{\circ} 30^{\prime}$ & $15 \cdot 5$ & $20 \cdot 3^{\circ} \mathrm{C}$. & 187 \\
5 & $0 \cdot 8534$ & $-2^{\circ} 45^{\prime}$ & $11 \cdot 7$ & $20 \cdot 6^{\circ} \mathrm{C}$. & 193 \\
\hline
\end{tabular}

This is a larger range than one would wish, and we hope $t$ ]

reduced to a considerable extent after further work, especially since we have so far been unable to invariably obtain good duplicates, the difference being sometimes as much as 4 per cent.

We next took samples of artificial otto and of a number of oils, either found by ourselves or said by other workers to be used as adulterants. As will be seen by the following table, these, with the exception of citronellol and citral, all gave absorp- 
tions well over 200 , geranium oils being the lowest with an absorption of 213 ; but, since these oils have a comparatively high ester content, their presence is at once demonstrated by the high potash absorption. A point worthy of note is that while artificial otto is considerably deodorized by iodine, the odour of the natural oil is not affected :

\begin{tabular}{|c|c|c|c|c|}
\hline Oil. & $\begin{array}{c}\text { Iodine } \\
\text { Number. }\end{array}$ & Oil. & & $\begin{array}{l}\text { Iodine } \\
\text { Number. }\end{array}$ \\
\hline $\begin{array}{ccr}\text { Artificial otto } & \text { with } \\
\text { stearoptene } & \ldots & \ldots \\
\text { Artificial otto } & \text { without } \\
\text { stearoptene } & \ldots & \ldots \\
\text { Palma rosa } & \ldots & \ldots \\
\text { Geranium, } & \text { African } & \ldots \\
\text { ", } & \text { Bourbon } & \ldots \\
\text { " } & \text { Spanish } & \ldots\end{array}$ & $\begin{array}{l}221 \text { to } 254 \\
261, " 279 \\
296, " 307 \\
213 \not 225 \\
213, " 215 \\
211\end{array}$ & $\begin{array}{ll}\text { Geraniol } & \ldots \\
\text { Citronella } & \ldots \\
\text { Citronellol } & \ldots \\
\text { Linalol } & \ldots \\
\text { Citral } \ldots & \ldots \\
\text { Guaiacum wood } \\
\text { Stearoptene } & \ldots\end{array}$ & $\begin{array}{l}\cdots \\
\cdots \\
\cdots \\
\cdots \\
\cdots \\
\cdots \\
\cdots\end{array}$ & $\begin{array}{c}239 \text { and } 307^{*} \\
217 \\
187 \\
280 \\
175 \\
298 \\
\text { None }\end{array}$ \\
\hline
\end{tabular}

Having obtained these results, we applied the process to a number of samples submitted to us from time to time, and which we had rejected as being of suspiciously poor odour, adulterated, or suspected of adulteration, and, as will be seen by the following table, we were confirmed in our opinion in each case :

\begin{tabular}{l|c|c|c|c|c}
\hline No. & $\begin{array}{c}\text { Specific Gravity } \\
\frac{30^{\circ}}{15 \cdot 5^{\circ}} \mathrm{C.}\end{array}$ & $\begin{array}{c}\text { Rotation } 30^{\circ} \mathrm{C} ., \\
100 \text {-millimetre } \\
\text { Tube. }\end{array}$ & $\begin{array}{c}\text { Saponification } \\
\text { Number. }\end{array}$ & $\begin{array}{c}\text { Setting- } \\
\text { Point. }\end{array}$ & $\begin{array}{c}\text { Iodine } \\
\text { Number. }\end{array}$ \\
\hline & $0 \cdot 8552$ & $-2^{\circ} 45^{\prime}$ & $8 \cdot 9$ & $20 \cdot 8^{\circ} \mathrm{C}$. & 219 \\
2 & $0 \cdot 8561$ & $-2^{\circ} 47^{\prime}$ & $8 \cdot 4$ & $19 \cdot 2^{\circ} \mathrm{C}$. & 212 \\
3 & $0 \cdot 8554$ & $-2^{\circ} 42^{\prime}$ & $8 \cdot 1$ & $19 \cdot 8^{\circ} \mathrm{C}$. & 206 \\
4 & $0 \cdot 8581$ & $-1^{\circ} 24^{\prime}$ & $10 \cdot 3$ & $21 \cdot 3^{\circ} \mathrm{C}$. & 234 \\
5 & $0 \cdot 8797$ & $-19^{\circ} 50^{\prime}$ & $40 \cdot 8$ & $28 \cdot 4^{\circ} \mathrm{C}$. & 142 \\
7 & $0 \cdot 8434$ & $-0^{\circ} 47^{\prime}$ & $16 \cdot 1$ & $18 \cdot 5^{\circ} \mathrm{C}$. & 133 \\
8 & $0 \cdot 8659$ & $-1^{\circ} 24^{\prime}$ & $17 \cdot 3$ & $16 \cdot 8^{\circ} \mathrm{C}$. & 245 \\
\hline & $0 \cdot 8550$ & $-2^{\circ} 2^{\prime}$ & $9 \cdot 8$ & $20 \cdot 6^{\circ} \mathrm{C}$. & 215 \\
\hline
\end{tabular}

Of these samples, in Nos. 1 and 2 we suspect the presence of geraniol and in No. 3 artificial otto. Nos. 4 and 7 appear to be chiefly artificial, No. 5 is grossly adulterated, but the quantity submitted did not allow of a thorough investigation. No. 6 contained a considerable quantity of alcohol, and No. 8 is the mixture (artificial 1 and genuine otto 2) already mentioned. A point yet to be determined is the time required for complete saturation, for, although we have made most of our determinations after three hours' standing, it is certain that the reaction is not complete by then. So far we have found that the absorption takes place rapidly to commence with, and then slowly up to at least forty-eight hours, but we have not obtained closer duplicates at any interval between three and forty-eight hours than we have at the end of the first-

* Distinctly different oils. The latter apparently artificial, the other natural. 
named period, and so have confined ourselves rather to the finding of the exact conditions under which regular absorption takes place than to the point of saturation, as a process which takes forty-eight hours to complete can hardly be said to recommend itself.

We are still working on this subject, and hope to give another note at a future meeting.

\section{Discussion.}

The President (Mr. Fairley) inquired whether in the case of the sample which contained 20 per cent. of alcohol any other adulterant had been found. Sample No. 6 seemed a peculiar one, and it would be interesting to hear how the authors accounted for its very low iodine absorption.

Mr. L. Myddelton NASH asked what were the constituents in these oils that combined with the iodine. The stearoptene, of course, which constituted a large proportion of the oil, did not combine with iodine at all. He should also like to hear at what temperature the specific gravity of the otto was taken. At ordinary temperatures it would be solid.

Mr. Chapman said that substances like citronellol, linalol, geraniol, and so on, were extremely reactive bodies, very unstable, and liable on the slightest provocation to undergo intramolecular change, sometimes accompanied by changes in the degree of their unsaturatedness. In attempting to prepare bromine addition compounds from some of the terpenes one often found that a great deal depended upon whether the addition was effected in some one particular solvent in preference to some other, or at a very low as distinguished from merely a low temperature, or even in darkness or in light. The fact that such comparatively small differences in the conditions of working were capable of exercising so great an influence on the product obtained, together with the liability to intramolecular change, seemed to indicate that the absorption of iodine in these cases was frequently by no means a simple process of addition. Experience showed that in the case of unsaturated fatty compounds the Hübl addition compounds were very complicated, and this seemed to be also the case with the compounds under discussion. Geraniol and linalol being both alcohols containing two doubly-linked pairs of carbon atoms, while citronellol had only one such pair, if there was a simple addition of halogen it might be expected that the numbers for geraniol and linalol would be, roughly, twice those for citronellol. $\mathrm{He}$ did not quite understand the figures which the authors had obtained for geraniol. Geraniol was, of course, a definite chemical compound-a detinite alcohol-and it was hard to see how two samples could yield numbers so widely separated as 239 and 307. Even assuming the sample yielding the former figure to be exceptional and very impure, the absorption of the other was by no means twice that of the citronellol, which would be the case if it were a simple process of addition. This brought him to a suggestion which he would like to make to the authors, that they should try working in a somewhat different way-namely, by running a well-cooled solution of bromine in glacial acetic acid, chloroform, or some other solvent into a thoroughly well-cooled solution of the otto of roses or other substance under experiment. This would, at any rate, tend to minimize intramolecular change, and, 
he thought, to produce more simple addition compounds. In that case any difference in ansaturatedness between these various bodies would probably have a much more marked effect on the numbers, which would, in consequence, be rendered more generally useful.

Mr. Archbutr suggested that it would be desirable to state, in connection with these results, how long the oils were allowed to remain in contact with the Hübl solution, whether the determinations were carried out in the light or in darkness, and what excess of iodine was left at the end of the process. Although he had had no personal experience in regard to essential oils generally, he had made a large number of determinations of the iodine absorption of oil of turpentine, and had long since abandoned the use of Hübl solution, having obtained much more satisfactory results with Wijs's solution. Iodine undoubtedly continued to be taken up as long as contact was allowed, substitution no doubt taking place after the formation of the primary addition compound. In practice, however, in the case of oil of turpentine, one could learn all one wanted to know by allowing the Wijs solution to act for twenty minutes, and during that time it did not matter whether the action took place in darkness or in the light. He laid great stress on the exact number of minutes being adhered to, as there was a considerable difference between the amount of iodine absorbed by oil of turpentine during twenty minutes and that absorbed during an hour or even half an hour. This he had ascertained from a number of determinations made with the same sample, in which the action was allowed to go on for varying periods up to as long as seventy-two hours. The amount of iodine left unabsorbed at the end of the test also greatly influenced the absorption; it should be as nearly as possible equal in amount to the quantity taken up.

Mr. Hudson-Cox said that in the case of sample No. 6 an excess of stearoptene had undoubtedly been added to bring up the setting-point, but no further examination had been made of the sample. Otto of rose being an expensive substance, it was the custom for samples to be paid for, but in this case the sample was of such poor quality that it was returned forthwith. The specific gravity of the otto had been taken in each case at $30^{\circ} \mathrm{C}$., as compared with water at $15.5^{\circ} \mathrm{C}$. With regard to the samples of geraniol, one of these (iodine number 239) was natural geraniol, probably from Palma rosa, of which it had a distinct odour. The other, apparently artificial, was purer; it had no rotation at all.

Mr. Chapman remarked that the first sample must be very impure, and it was important to bear in mind that the numbers it yielded could not be taken as applying to pure geraniol, which was a definite chemical compound.

Mr. Hudson-Cox, continuing, said that there could be no doubt as to the complexity of the reaction, but they were able to obtain in most cases duplicate results which agreed fairly well. The process, however, was not applicable to all essential oils. With regard to the conditions of working, all the determinations had been made in the dark, and various periods of contact had been tried, from three hours up to forty-eight hours. The change was certainly not complete in less than forty-eight hours, but it took place very rapidly up to about three hours, and then very slowly ; and, as they had found that the results obtained after a longer period were no more concordant than those after three hours' contact, three hours had been adopted. 
Mr. Chapman said that if bromine were used all the absorption required to satisfy the double linkage would take place in a few minutes, and the end-point would be fairly sharp.

Mr. Hudson-Cox, continuing, said that the amount of iodine in excess was kept at about the same as that absorbed. They had tried the use of Wijs's solution, but could not get a satisfactory end reaction.

Mr. Archiutr was surprised to hear that, and inquired whether any difficulty had been experienced in getting a constant absorption.

Mr. Hudson-Cox said that the difficulty was in titration. Decolorization was no sooner obtained than the colour began to come back again.

Mr. Chapman said that possibly hydrogen peroxide was formed, which would constantly liberate iodine.

Mr. Hudson-Cox said that that was probably so, and he would have expected the same thing to occur in the case of oil of turpentine.

Mr. Archintt said that turpentine absorbed about 300 per cent. of iodine in twenty minutes under the conditions he had specified. The end-point was quite sharp in titrating, and closely agreeing results could be repeatedly obtained with the same sample. 